\title{
Empowerment Model for Sustainable Tourism Village in an Emerging Country
}

\author{
Singgih PURNOMO*, Endang Siti RAHAYU ${ }^{* *}$, Asri Laksmi RIANI ${ }^{* * *}$, \\ Suminah SUMINAH ${ }^{* * * *}$, Udin UDIN ${ }^{* * * * *}$
}

Received: November 24, 2019 Revised: December 11, 2019 Accepted: December 18, 2019

\begin{abstract}
This study aims to examine the community empowerment model to develop sustainable tourism villages in Indonesia. This study applies a qualitative method. Data collection is conducted through interviews, observations, and focus group discussions held in Ponggok Village of Central Java Province - Indonesia. The results of this study found that the tourism development carried out in the Ponggok Village used four approaches (1) spatial approach as a basis in determining the direction of village development; (2) sectoral approach through increasing the role of the Village Owned Enterprises to build the village economy; (3) human resources to enhance the role of village communities in managing village potentials; and (4) use of information technology to improve service quality, transparency and accountability. The success of these four approaches is influenced by the leadership, innovation, collaboration, and good village governance. The success of the Ponggok village to become an independent village in improving the welfare of the community is inseparable from the success of the Ponggok village government in empowering the community to manage sustainable tourism development. The success of development with these four approaches is influenced by leadership, innovation, collaboration, and good governance.
\end{abstract}

Keywords: Empowerment, Tourism Village, Sustainable Tourism, Indonesia

JEL Classification Code: L83, Q01, Z32

\section{Introduction}

At present, tourism is a central component in the development of the world economy and is one of the primary sources of income for developed and developing countries (Costa, 2017; Mason, 2015). The contemporary tourism market offers a variety of cultural, social, technological, experiential, and natural products for leisure and business. This has become a strong foundation for sustainable development in many regions of the world (Turner \& Freiermuth, 2016). But to be able to increase this

${ }^{*}$ First Author. Fakultas Pasca Sarjana, Universitas Sebelas Maret, Indonesia. Email: singgihpurnomo@student.uns.ac.id

** Fakultas Pasca Sarjana, Universitas Sebelas Maret, Indonesia

*** Fakultas Pasca Sarjana, Universitas Sebelas Maret, Indonesia

**** Fakultas Pasca Sarjana, Universitas Sebelas Maret, Indonesia

$* * * * *$ Corresponding Author. Business and Economic Faculty, Universitas Muhammadiyah Yogyakarta, Indonesia [Postal Address: JI. Brawijaya, Tamantirto, Kec. Kasihan, Yogyakarta, 55183, Indonesia] Tel.: +62 85343709228

Email: udin_labuan@yahoo.com

$\odot$ Copyright: Korean Distribution Science Association (KODISA)

This is an Open Access article distributed under the tems of the Creative Commons Attribution NonCommercial License (https:///creativecommons.org/licenses/by-nc/4.0/) which permits unrestricted noncommercial use, distribution, and reproduction in any medium, provided the original work is properly cited. positive effect requires a lot of resources and competencies to increase tourist satisfaction with a variety of exciting experiences at the tourist destinations visited (Sheresheva \& Kopiski, 2016).

Since 2017 it has been designated the International Year for Sustainable Tourism with the theme "Well-designed and well-managed tourism (UNWTO/WTCF, 2018). It can be said that any country that aims to improve competitiveness in the global tourism market must pay special attention to the issue of sustainable tourism and good tourism management practices (Edgell Sr, 2016; Farmaki, 2015; Mowforth \& Munt, 2008). Tourism development must also take into account global tourism trends that affect management patterns and consumer needs. The government and tourism businesses must be able to develop digitalization. The use of robotics and artificial intelligence technology, big data analysis, economic sharing, social media, and rapidly evolving technologies can increase consumer interest in evaluating and utilizing tourism products offered by tourism actors (Bowen \& Whalen, 2017).

In Indonesia, tourism has become a strategic sector. It is a medium of integration between various development 
sectors, so tourism is set to become a development priority in Indonesia through the development of tourism villages. According to Lane (2009), pure rural tourism is defined as the type of tourism located in a rural area. If someone wants to describe a holiday as a rural tour, the following characteristics must be included in the vacation. Should: (1) be placed in rural areas, (2) be based on rural tourism features, (3) have small scale buildings and settlements, (4) be connected with local communities and their families, (5) be based on villages and small cities, (6) represent complex economic, environmental and historical patterns (Lane, 2009). In Indonesia, there are 74,954 villages, and currently, 1,902 villages are being developed into tourist villages. This has resulted in the increasingly fierce competition in tourist villages in Indonesia. To be able to create a tourism village to develop and compete healthily, it is necessary for the role of all stakeholders to build a model of tourism village development in a sustainable manner (Reynaldi, 2018).

Apart from having a positive impact on tourism destinations, tourism development also hurts tourism destinations. If this is not managed on a sustainable basis, tourism will hurt local communities, damage to the natural environment, and unfair economic competition. Tourism development must be built on stable steps. The development of steady tourism has two concepts, namely the protection of the environment and its natural resources, and the second is the protection of social heritage. Thus, stable tourism must be carried out with clear policies to guarantee appropriate steps in comprehensive development (Bazneshin, Hosseini, \& Azeri, 2015).

Through Law No. 6 of 2014 concerning Villages, the Government of Indonesia has given high authority to villages to manage assets and increase village economic independence. Based on the Village Law, the village can form a Village-Owned Enterprise (BUMDes) that can improve the welfare of the community. Besides, the existence of the Village Law, the Indonesian government also assists villages through village funds, which increase every year. The success of utilizing village funds to improve community welfare occurred in Ponggok Village, Klaten Regency, Central Java Province, namely through the establishment of the BUMDes Tirta Mandiri. This VillageOwned Enterprise has a function to manage the potential of natural resources in the village to increase income for the community. The success of BUMDes Tirta Mandiri in empowering and managing village potential has resulted in Ponggok Village being awarded the Best National Tourism Village in 2017 for the Community Empowerment Category.

The success of the Ponggok village in obtaining the national award is exciting to study because it can be an inspiration for other regions in increasing the role of the village government to improve the welfare of the community. This is since the village of Ponggok, which was initially backward, is now an independent village with the welfare of its village residents increasing. The success of Village-Owned Enterprise in managing the village potential is passed through a hard struggle by the VillageOwned Enterprise management and the ability of the village head to motivate all the administrators involved. In the beginning, BUMDes Tirta Mandiri experienced many obstacles with the pessimism of some community leaders who did not believe that this institution could develop and bring change to improve people's welfare. Also, the limited human resources in Ponggok Village to manage VillageOwned Enterprise are a problem that must be solved by managers. Therefore, both the village government and Village-Owned Enterprise managers must jointly work to overcome these obstacles and prove to the community that Village-Owned Enterprise is a village government institution capable of managing Ponggok village tourism assets in improving community welfare.

The success of the Ponggok village government is inseparable from the role of the Ponggok Village Chief, who was very visionary in finding breakthroughs to improve the welfare of the community. One of the main roles carried out by the Village Head is to build community participation in developing villages through the establishment of BUMDes Tirta Mandiri, which plays a significant role in the development and management of tourist villages in Ponggok. At present, the people of Ponggok Village have significantly benefited from the hard work of their village heads and Village-Owned Enterprise, both in the economic, social, education, health, and environmental sustainability sectors. This success is inseparable from the programs implemented by the Village Government and Village-Owned Enterprise in empowering the community and developing sustainable tourism villages.

Sustainable tourism is programmed and performed using the concept of stable development in that it responds to the needs of the present generation, without depleting the capacity of the next generation, in a way that does not have a negative impact on the environment, economy, and culture of the host community (Zolfaghari, 2010). In Indonesia, the concept of developing a tourist village approach is known as the triple helix concept. The concept of triple helix is the concept of social and community transformation in human empowerment, including social power, environmental power, and economic power. Social power aims to raise the social ability of the community to create a productive society. Environmental power aims to generate development power to create a sustainable environment, and economic power aims to generate economic power to create a productive society (Indonesian Ministry of Tourism, 2019). The concept of sustainable 
tourism development emphasizes 4 (four) principles, as follows: 1) Economically feasible; 2) Environmentally Feasible; 3) Socially acceptable and 4) Technologically Appropriate.

The development of tourism villages has been carried out by many tourism villages in Indonesia. Still, the development of sustainable tourism villages carried out by the Ponggok village government and BUMDes Tirta Mandiri is exciting to study, especially in the aspect of community empowerment, because the Ponggok village government and BUMDes Tirta Mandiri have been successful in empowering the community especially in developing sustainable tourism villages. Because without good community empowerment, the participation and awareness of the community to establish rural tourism will below, so that tourism activities in the village will not develop properly. At present, there is a lot of development of tourism villages in Indonesia, but many villages are underdeveloped optimally because there is no institutional model that can manage tourism villages and the lack of village government experience in developing sustainable tourism villages. The various consequences that occur include rejection from the community, clashes between citizens in utilizing land income, lack of transparency in financial management, and less optimal development of rural tourism activities in improving community welfare.

\section{Literature Review}

Development or community empowerment in the tourism village is known as sustainable tourism. Sustainable tourism is planned and carried out using the concept of stable growth, namely tourism that answers the needs of the current generation, without depleting the capacity of the next generation, in a way that does not have a negative impact on the environment, economy, and culture of the community at the tourist destination (Zolfaghari, 2010). Tourism development can be done by improving transportation infrastructure, accommodation, entertainment, recreation, food, and shopping. This will make it easier for someone to travel, business, and leisure. The development of sustainable tourism is a top priority, but how to achieve it remains an object of debate by tourism businesses (Peeters \& Dubois, 2010).
A stable tourism activity occurs when tourism businesses can manage all the resources they have by protecting the environment and respecting cultural values in the community. Tourism actors can determine the satisfaction index of tourists to measure tourist satisfaction with the management of tourist destinations. There are many limitations in measuring tourist satisfaction, which can result in errors in analyzing tourist satisfaction data in a tourist destination. This is due to the satisfaction of tourists not only influenced by the nature of each individual but also the characteristics of each different region (Shie \& Alipor Eshliki, 2010).

Tourist loyalty is an essential variable measuring the management of tourist destinations. The number of studies on loyalty associated with tourist destinations shows that loyalty is a priority in the final destination of the business of managing tourist destinations in increasing their competitiveness. Research of Mostafavi Shirazi and Mat Som (2013) examined the factors of loyalty, namely the desire to visit again mediated by satisfaction. Loyalty to the proxy of the intention to recommend refers to the research of (Araslı \& Baradarani, 2014; Mostafavi Shirazi \& Mat Som, 2013; Yang, Liu, Jing, \& Li, 2014), the difference of these studies is the independent variable, so the data analysis methods are also different.

Loyalty is an essential variable for the sustainability of tourism businesses, especially rural tourism because it is the government's priority program in developing the welfare of rural communities. The effort to build tourist loyalty is a significant program, which must be carried out by the manager of the tourism object. With the increase in tourist loyalty, more tourists will return to a tourist destination and will recommend to other parties to want to visit the place so that the tourist destination will develop sustainably. The role of the Village Government in carrying out community empowerment to increase tourist satisfaction needs to be done in a planned and systematic manner by involving various related parties.

Based on the description above, it can be explained that for improving tourism competitiveness, the empowerment of the community is needed to be able to manage and provide excellent services to foster satisfaction for tourists. Empowerment is directed at increasing tourism competitiveness, including environmental support, policies, and conditions that support it, infrastructure, and natural and cultural resources. The flow of empowerment can be seen in the chart below:

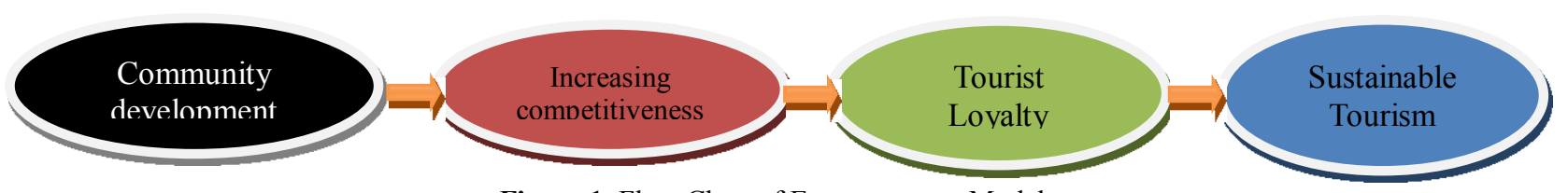

Figure 1: Flow Chart of Empowerment Models 
Based on the results of a review of the research review of (Bazneshin et al., 2015; Mason, 2015; Shie \& Alipor Eshliki, 2010), this study will examine the empowerment model for tourist villages in Ponggok Village, Klaten Regency, Central Java Province, Indonesia.

The concept of development in the Ponggok village is done through a spatial approach (spatial planning) as a basis in determining the direction of village development, a sectoral approach through increasing the role of the Village Owned Enterprises to develop the village economy, strengthening human resources to enhance the role of the village community in managing potential villages and the use of information technology to improve service quality, transparency and accountability, this aims to increase the competitiveness of tourism villages which are currently increasingly competitive. Increased competitiveness as a result of empowerment is expected to improve the sustainability of rural tourism, which in turn can improve the welfare of the village community.

\section{Research Methods and Materials}

This research was conducted in the Tourism Village of Ponggok, Klaten Regency, Central Java Province. Ponggok Village is a village that has several tourist attractions. The reasons for choosing Ponggok Village as a research location are The success of Ponggok Village through Village-Owned Enterprise by obtaining a national award as the best Village-Owned Enterprise in community empowerment to improve the welfare of Ponggok villagers. One of the factors of the success of Village-Owned Enterprise in promoting the welfare of rural communities is by revitalizing Ponggok Spring into an attractive and innovative tourist attraction, thus earning revenue in 2017 of more than Rp. 14 billion per year, this makes Ponggok Village an independent village.

This research was conducted in Ponggok Tourism Village, Regency. The research method used was a qualitative method, and the method of data collection was carried out through interviews, observations, and focus group discussions. Focus Group Discussion is a data collection method commonly used in qualitative social research. The informants in this study were the Ponggok village government, Ponggok village residents, Ponggok village institutions, Tourism Awareness Group, district government, industry, academia, and tourists.

\section{Results and Discussion}

The birth of Law No. 16 of 2014 made a very positive contribution to the development of villages in Indonesia because it resulted in increased village funds, increased village authority in managing village assets, and further increased village autonomy in managing the budget by existing regulations. The positive impact if the village can manage village funds appropriately will bring prosperity to its citizens. On this basis, the head of Ponggok Village developed development with four approaches, namely: the spatial approach (spatial planning), the sectoral approach, the human resource development approach, and the information technology approach. This is stated in the Ponggok village Long-Term Development Plan. Based on the visionary leadership of the village head and excellent managerial skills, the four approaches can be implemented well so that the village of Ponggok becomes an independent village, which results in increasing community welfare. The approach taken by the Ponggok Village government is described as follows:

\subsection{Spatial Approach (Spatial Planning)}

To explore the potential of tourism in the village of Ponggok, the village government of Ponggok has taken a spatial approach to guide the basic framework of rural development and is a document that reflects all development plans in a rural area. This spatial approach also addresses the problems and demands of development needed by the Village Government and the community in the future.

In this spatial approach activity, the Ponggok village government collaborated with the University of Gajah Mada Yogyakarta in mapping the geographical, demographic, and potential areas of each region in Ponggok Village. Based on the results of the mapping obtained spatial maps, maps of potential locations of natural potential, agriculture, fisheries, culture, and other village potentials. Also, a map of Ponggok Village's tectonic earthquake-prone areas, fire-prone areas, and slumstructured maps were obtained. Based on this mapping, an analysis of the potential of the Ponggok village tourism area and planning for the development of an integrated tourism area in the Ponggok village are outlined in the village's Medium-Term Development Plan. The preparation of the integrated Ponggok tourist area masterplan is adjusted to the functions and planning needs, which include elements of education, entertainment, accessibility, empowerment of small communities, environmental conservation, and sociocultural communities, as well as architecture and the environment.

To running the village mid-term development plan, the village head involves elements from higher education, local government, industry, the community, and the media (Quintuple Helix). Higher education has a role in mapping the potential and problems that exist in the village of 
Ponggok and helping in community empowerment and MSMEs. The regional or central government has a role in facilitating the development of tourism facilities and infrastructure, such as road infrastructure, in facilitating access to the village of Ponggok. The industrial world is invited to work together to help social activities, providing business capital assistance for MSMEs. The role of the community in the Ponggok tourism village is to maintain the tourist environment to remain comfortable and safe to visit and to improve environmental conservation to remain sustainable. For mass media, the role is to promote tourism objects in Ponggok village and publicize Ponggok tourism village activities to the wider community, so that Ponggok tourism villages are increasingly popular.

Cooperation and support between stakeholders are crucial for the sustainability of rural tourism. This collaboration and support will be an effective strategy for tourism development in the rural sector. According to Ezeuduji (2015), stakeholders in local tourism destinations can work together in managing rural tourism development, so that tourism destinations in the village can be competitive and sustainable. In addition to stakeholders (central government, local government, village government, universities, industry, and media) in rural tourism, rural communities must also be involved in the development of rural tourism, because rural tourism cannot be successful without community support (Falak, Chiun, \& Wee, 2014).

Support and collaboration between stakeholders with various parties in the development of development have been carried out. Etzkowitz and Leydesdorff (1995) develop the Triple Helix model, which adopts a spiral innovation model (versus traditional linear) that captures several reciprocal relationships between institutional arrangements (public, private, and academic) at different stages in the capitalization of knowledge (Viale \& Ghiglione, 1998).

\subsection{Sectoral Approach}

To develop tourism potential based on the results of spatial analysis, the Ponggok village government took a sectoral development approach. The sectoral approach taken by the Ponggok village government is to develop commodities and productive businesses by optimizing the role of Village-Owned Enterprise (BUMDes) as the locomotive of village economic development by managing the business professionally like a company to obtain profits that can be distributed to shareholders or investors.

Village-Owned Enterprise is tasked with managing the potential of natural resources in the village as an income field for the community. BUMDes Tirta Mandiri Ponggok currently manages Ponggok Spring tours, Village Stores, Ponggok Ciblon, Village Study Management, Capilaler
Springs, SMEs Management, and aquaculture. The development of BUMDes Tirta Mandiri's income can be seen in Table 1.

Table 1: BUMDes Tirta Mandiri Income

\begin{tabular}{|c|c|r|}
\hline Years & $\begin{array}{c}\text { Gross Revenue } \\
\text { (Rp) }\end{array}$ & $\begin{array}{c}\text { Revenue Share ForVillage Income } \\
\text { (Rp) }\end{array}$ \\
\hline 2012 & 150.000 .000 & 70.000 .000 \\
2013 & 211.000 .000 & 80.000 .000 \\
2014 & 1.100 .000 .000 & 350.000 .000 \\
2015 & 6.100 .000 .000 & 810.000 .000 \\
2016 & 10.300 .000 .000 & 1.200 .000 .000 \\
2017 & 14.200 .000 .000 & 1.290 .000 .000 \\
\hline
\end{tabular}

Source: BUMDes Tirta Mandiri (2017)

Table 1 shows that since 2013, the income of Ponggok Village has only reached $\mathrm{Rp} 211$ million, rising to $\mathrm{Rp} 1.1$ billion in 2014 and 2016, jumping to Rp 10.3 billion. Then in 2017, it will be Rp. 14.2 billion. This increase in income has an impact on the increase in Village Original Revenues. In 2013 the contribution to Village revenue was Rp. 80 million, but in 2017 it increased to Rp. 1.29 billion. This shows that BUMDes Tirta Mandiri's income is increasing every year.

The most significant contribution of income obtained by BUMDes Tirta Mandiri comes from the Ponggok Spring tourism object, which reaches $80 \%$, meaning that income dependence is still concentrated on Ponggok Spring income through tourist visits to the object. While for other businesses, they have not significantly contributed. However, BUMDes Tirta Mandiri continues to make breakthroughs, including Clean Water Management, fish pond rental, culinary kiosk and shop rental, car rental, and management of the village financial sector, which includes revolving loans for the poor and capital loans for middleclass citizens. However, these other businesses still depend on their finances on the Ponggok Spring tourism business, which shows that business in other fields is not yet independent.

One significant role of BUMDes Tirta Mandiri is the empowerment of MSMEs in Ponggok Village. MSMEs in the village of Ponggok, both those around tourism objects and those outside tourism objects, are given training and assistance in running their businesses. In collaboration with the family welfare empowerment group, BUMDes Tirta Mandiri has helped market MSME products in Ponggok village through village shops and sales of products bundled with ticket prices at tourist attractions. In this way village, MSMEs products can be sold quickly. With the increasing number of comparative studies from various regions both inside and outside the village of Ponggok, Village-Owned Enterprise cooperates with tourism awareness groups to develop village studies, namely educational tours to learn about the management of Village-Owned Enterprise, 
MSMEs, agriculture, animal husbandry, etc. Besides, Village-Owned Enterprise and tourism awareness groups also sell tour packages by collaborating with tourism object managers in Central Java and Yogyakarta in particular, as well as in other regions as business development to increase revenue and reduce competition among tourism object managers, so that tourism sustainability can be maintained well.

To improve the economic welfare of the community, BUMDes Tirta Mandiri provides the opportunity for Ponggok villagers to invest in Village-Owned Enterprise in the form of shares. Currently, 500 Ponggok residents have invested in Village-Owned Enterprise, and they earn an average income of $10 \%$ of the value of the invested shares. This is very beneficial for villagers to increase their income. With this stock, an investment can increase the sense of ownership of the community towards the sustainability of Village-Owned Enterprise and tourism because the more significant Village-Owned Enterprise revenue and tourism revenue can also increase the amount of income from shares invested in Village-Owned Enterprise.

To carry out sectoral development, the Ponggok village government and Village-Owned Enterprise collaborate with the industry, academia, and consultants by their respective expertise. For example, for infrastructure development, the village government cooperates with consultants from the architects. For community empowerment, the consultants work together with consultants from National Community Empowerment Program for tourism activities, collaborating with academics and tourism associations, as well as district and national tourism communities who have experience. This is in line with the thoughts of Carayannis and Campbell (2009), stating the importance of government, university, and industry policies and civil society interacting intelligently, effectively, and efficiently.

The results of this study also support the research of Reynaldi (2018), in tourism-aware groups requiring professional roles in managing structures and systems. The lack of a professional role makes the process of developing tourism activities slow. Collaboration and innovation in harmony with the development of globalization are required to be able to adapt well.

\subsection{Institutional and Human Resources Approach}

The next development approach taken by the Ponggok village government is to strengthen institutions and improve the quality of human resources in the management of tourism in the Ponggok village. In institutional strengthening and human resource enhancement activities are carried out to realize good governance through good service training to the public and tourists, information technology training, village institutional capacity building namely Village Representative Body, Community Empowerment Institute, Family Welfare Empowerment, Integrated service post, Youth Organization, Neighborhood Association, and Community Unit.

Considering that community participation is needed in the development of villages, the village government also conducts training to increase community participation in the development process, for example the creation of public facilities carried out cooperatively, disaster mitigation training, Village-Owned Enterprise management training, SMEs business management training, economic management training household, improvement of tourism community management, English course for tour guide and others. In addition to the institutional capacity and human resource development program, the village government and Village-Owned Enterprise also have excellent programs for Ponggok villagers, including 1) Smart Cards, a one-house one undergraduate program. 2) Health card, which is a program of providing health facilities for the community, 3) Mother and Child Card, namely providing health services for pregnant, breastfeeding and toddlers, and 4) Entrepreneurial Card, which is a service card for community business activities. These programs have been implemented well by the Ponggok village government and Village-Owned Enterprise and received excellent support from the villagers of Ponggok.

Empowerment in the village of Ponggok is in line with the opinion of Tolkach and King (2015), which states that one of the efforts to empower the community to reduce poverty that is being implemented is the concept of community empowerment by forming a tourism village. Tourism villages can be one way to reduce poverty, reduce unemployment, reduce inequality, and create jobs (Cahyono, Kurniawan, \& Kantun, 2018). Because by building a tourist village, it will help create an independent village, and create opportunities for the village economy to get better (Pan, Xu, Huang, \& Wang, 2018).

Population support for tourism is a core aspect of tourism sustainability (Choi \& Murray, 2010; Nunkoo, Smith, \& Ramkissoon, 2013; Yu, Chancellor, \& Cole, 2011). The main theory used to explain population support for tourism is the Social Exchange Theory (SET), which states that social interaction (or support for tourism in this case) is an exchange based on perceived rewards and relationship costs (Strzelecka, Boley, \& Strzelecka, 2017). In the context of tourism, visitor host interactions aim at maximizing benefits and minimizing tourism-related costs (Strzelecka et al., 2017). Community members weigh the potential benefits and risks of tourism. A positive attitude towards tourism and support for development more reflects a situation where the benefits of tourism outweigh the costs of tourism. However, if the perceived risk associated with 
tourism exceeds reward, residents are more likely to abandon their involvement in tourism exchange, and host community support for this type of development is reduced (Strzelecka et al., 2017).

\subsection{Information Technology Development Approach}

The development of information technology has made the Ponggok Village Government also make a breakthrough with the concept of e-Governance as an effort to improve internet-based public services. The use of information technology has driven Internet penetration into villages and has become a social movement, "IT Literacy Village." Information technology has been utilized by the Ponggok village government for population services, public administration services, village databases, and village websites. The existence of this information technology has made it easier for Ponggok villagers to manage population and access information on various activities in the village.

In conjunction with the use of this information technology, various activities and information in the Ponggok tourism village can be accessed by the wider community so that the existence of the Ponggok tourism village is increasingly recognized by the public. Many studies suggest that there has been a significant shift in traditional flight bookings to online bookings in the coming years due to experience-based improvements (Travelport, 2017). In addition to researching the use of consumer ICT in the search for travel information descriptively, several researchers have investigated and learned how online consumer search behavior has changed over time. Longitudinal studies by Xiang, Wang, O'Leary, and Fesenmaier (2015) confirm that travelers out of America are now fully adapted to the internet because their perceptions of internet security, trust, and personal services are significantly improved. Despite the increasing role of social media and cellular technology in online travel planning, resources, such as newspapers and television, are still seen as complementary to various international media.

Based on the results of these studies, the Ponggok village government and Village-Owned Enterprise are currently also very aggressively conducting promotions through internet media or digital marketing. In addition to the needs of villagers, information technology has also been used by the Ponggok village government and Village-Owned Enterprise, and the tourism community for the development of tourism in the village. This information and communication technology is used for marketing management, tourist database management, or making it easier for tourists to communicate with relatives and friends, thereby increasing tourist satisfaction. This is by research conducted by Chevers and Spencer (2017), who found that
Information and Communication Technology influences tourist satisfaction. The presence of promotional media also affects the success of Ponggok village in attracting tourists to Ponggok through its website, Instagram, and other social media.

The village government of Ponggok, Village-Owned Enterprise, and the village community realize the importance of tourism sustainability in the village of Ponggok because this concerns the livelihoods of Ponggok villagers in the future. Therefore, the Ponggok tourism village must improve its tourism competitiveness. Efforts made by the government of Ponggok village so that tourism in Ponggok can be sustainable is to increase tourism competitiveness in the village of Ponggok, given the current competition of tourist villages. To develop competitive and sustainable tourism villages, in addition to using four approaches, namely spatial (spatial) approach as a basis in determining the direction of village development, sectoral approach through increasing the role of Village-Owned Enterprises to develop the village economy, enhancing human resources to strengthen the role of village communities in managing village potentials and the use of information technology to improve service quality, transparency and accountability.

The Government of Ponggok and Village-Owned Enterprise created a program to guarantee the sustainability of the tourism village, namely: First, involving Ponggok villagers to invest in Village-Owned Enterprise so that the income of Ponggok villagers increased and the sense of ownership of Ponggok villagers towards tourism sustainability in Ponggok was even more significant. Second, Village-Owned Enterprise cooperates with the management of tourist destinations around Ponggok Village, Central Java, and Yogyakarta to create tour packages, to reduce competition between tourist destinations that have a negative impact. Third, the Ponggok village government and the villagers are now reforested by planting the gayam tree as an icon of Ponggok village. This is done to preserve nature in the Ponggok village so that it is maintained. Fourth, Village-Owned Enterprise, in collaboration with the tourism community, has developed a village study, which is an educational tourism program for other villages or tourists who will develop their village to become a tourist village.

Based on the explanation of the concepts of development and community empowerment in the village of Ponggok, it can be concluded that the spatial approach (spatial planning) as the basis / reference for the direction of village development, sectoral approach to develop the village economy so that it becomes an independent village, human resource approach to strengthen village government and community capacity in managing village potential and information and communication technology (ICT) 
approaches to improve service quality, transparency and village can be seen in Figure 2. accountability. The development concept model in Ponggok

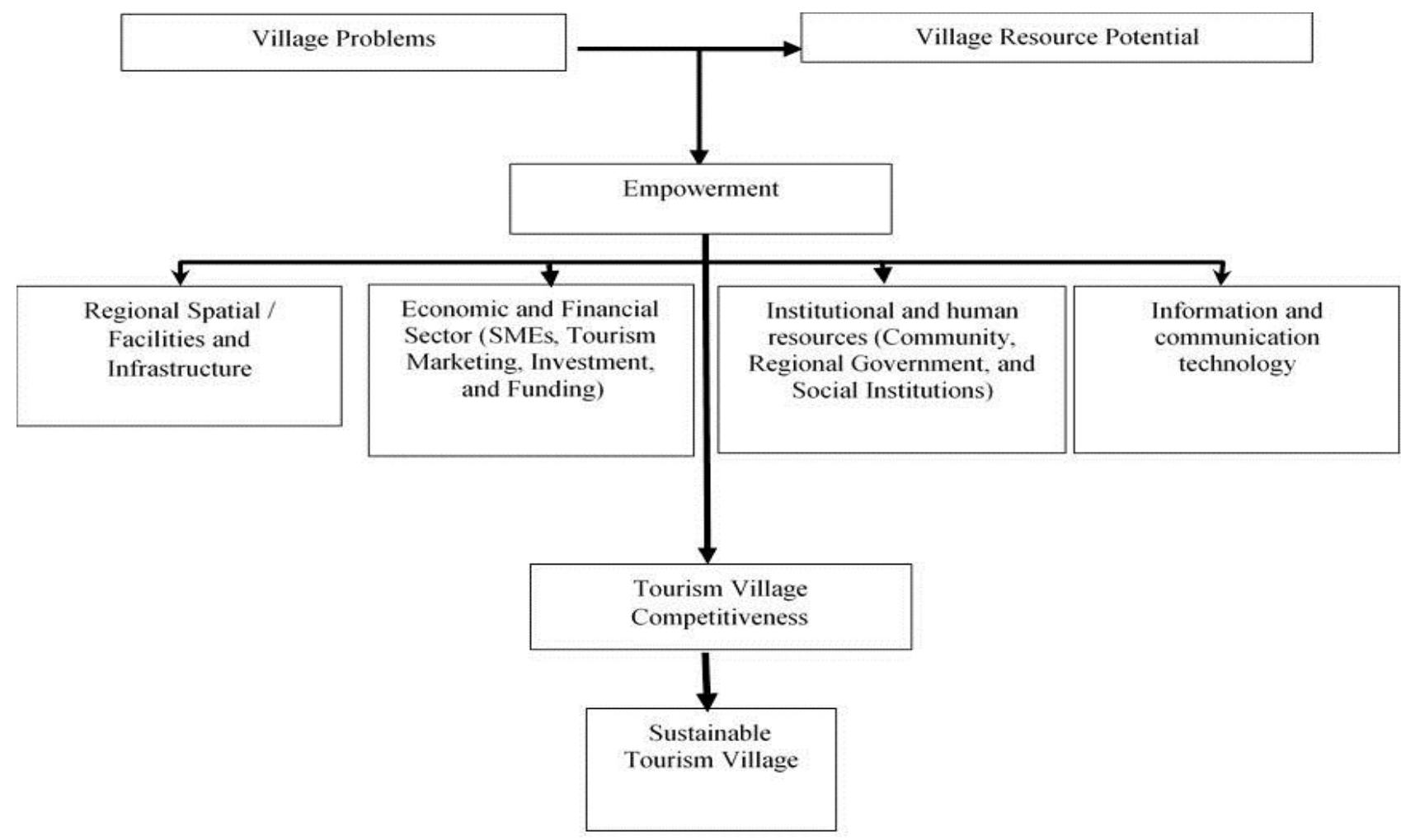

Figure 2: Concept of Sustainable Tourism Village Development

The results of the analysis and findings in the field show that the key to successful development of the Ponggok village to become an independent, competitive and sustainable village, especially in carrying out community empowerment programs and the development of a tourism village is located in the factors of leadership, innovation, collaboration, and governance good governance. On the leadership factor, the Ponggok village head is a visionary leader and has strong leadership. The dreams of building a Ponggok village, which was originally an impoverished village into an independent village has been realized within three years of his leadership. The village head of Ponggok is a democratic type of leader. This can be seen from the mechanism in making policy, always asking for input from the residents of his village (bottom-up) and proposals from the citizens to be consulted together to decide the best policy.

The innovation factor is one of the keys to the success of Ponggok village in developing its tourist destinations, one of the innovations that became the mainstay of Ponggok village is taking photos underwater (Underwater selfie) in Ponggok Spring. This underwater selfie makes Ponggok village very famous and is the primary income for Ponggok village from tourism. Besides under selfies, another tourism development innovation is a village study. The village study is a tour package program developed by the village government of Ponggok, Village-Owned Enterprise, and tourism community to serve tourists who want to know about village life such as farming, raising livestock, or learning to manage tourism villages. This village is the second contributor to income after water tourism. Another innovation is the ownership of Village-Owned Enterprise shares for Ponggok villagers. The existence of VillageOwned Enterprise share ownership can increase the income of Ponggok villagers, the average stock gain of around 7\% per month from the value of the investment invested.

The collaboration factor or cooperation with various parties is also the key to the success of the Ponggok tourism village in realizing an independent tourism village. Ponggok Village in achieving development uses the septuple helix model, which is a collaboration with seven institutions or elements of society such as the central or regional government, universities, industry, tourism community, media, investors, and competitors. This collaboration is a substantial capital for Ponggok village to develop a sustainable tourism village. 
Good governance is a vital key to success, especially to foster the trust of villagers, investors, or other stakeholders. Ponggok Village implements governance with the principles of transparency and accountability. Each community is it villagers or stakeholders can access various public information such as village financial management, Village-Owned Enterprise financial management, or other information. To facilitate access to information for the community, the Ponggok village government has developed information and communication technology in the form of village websites, social media accounts to communicate with villagers or tourists such as Instagram, Facebook, and WhatsApp.

The program carried out by the Ponggok Village Government is almost the same as a cross-sector partnership. Cross-sector partnerships are new models of collaboration between the public, business people, and/or non-profits. The cross-sector partnership is an embodiment of collective social entrepreneurship, which is defined as "a collaboration between similar and diverse actors to apply business principles to solve social problems" (Montgomery, Dacin, \& Dacin, 2012). This new organizational arrangement facilitates the acquisition, distribution, and creation of resources by many actors through various strategies with the ultimate goal of encouraging social change. The nonprofit business partnership literature, in particular, has conceptualized cross-sector partnerships as a multi-dimensional and multilevel value creation vehicle that arises because no actors have successfully overcome social problems, not to mention creating new solutions for them (Austin \& Seitanidi, 2012).

\section{Conclusion}

The success of the Ponggok village to become an independent village in improving the welfare of the community is inseparable from the success of the Ponggok village government in empowering the community to manage sustainable tourism development. The development carried out in Ponggok village uses four approaches, namely: a spatial approach as a basis / reference for the direction of village development, a sectoral approach through Village-Owned Enterprise institutional development to build the village economy, a human resource approach to strengthen the capacity of the village government and the community in managing potential villages and the use of information technology to improve service quality, transparency and accountability. The success of development with these four approaches is influenced by leadership, innovation, collaboration, and good governance.

\section{References}

Arasl1, H., \& Baradarani, S. (2014). European tourist perspective on destination satisfaction in Jordan's industries. Procedia-Social and Behavioral Sciences, 109, 1416-1425.

Austin, J. E., \& Seitanidi, M. M. (2012). Collaborative value creation: A review of partnering between nonprofits and businesses: Part I. Value creation spectrum and collaboration stages. Nonprofit and Voluntary Sector Quarterly, 41(5), 726-758.

Bazneshin, S. D., Hosseini, S. B., \& Azeri, A. R. K. (2015). The physical variables of tourist areas to increase the tourists' satisfaction regarding the sustainable tourism criteria: Case study of Rudsar Villages, Sefidab in Rahim Abad. Procedia-Social and Behavioral Sciences, 201, 128-135.

Bowen, J., \& Whalen, E. (2017). Trends that are changing travel and tourism. Worldwide Hospitality and Tourism Themes, 9(6), 592-602.

Cahyono, A. E., Kurniawan, M. U., \& Kantun, S. (2018). Community Empowerment Models of Tourism Village Based on Superior Commodities: Realizing Economic Resilience. Journal of Distribution Science, 16, 29-36.

Carayannis, E. G., \& Campbell, D. F. (2009). 'Mode 3'and'Quadruple Helix': toward a 21st century fractal innovation ecosystem. International Journal of Technology Management, 46(3-4), 201-234.

Chevers, D., \& Spencer, A. (2017). Customer satisfaction in Jamaican hotels through the use of information and communication technology. Worldwide Hospitality and Tourism Themes, 9(1), 70-85.

Choi, H. C., \& Murray, I. (2010). Resident attitudes toward sustainable community tourism. Journal of Sustainable Tourism, 18(4), 575-594.

Costa, J. (2017). How are companies and destinations "surfing the wave" of global tourism? Strategic question overview. Worldwide Hospitality and Tourism Themes, 9(6), 588-591.

Edgell Sr, D. L. (2016). Managing sustainable tourism: A legacy for the future. Abingdon, UK: Routledge.

Etzkowitz, H., \& Leydesdorff, L. (1995). The Triple Helix-University-industry-government relations: A laboratory for knowledge based economic development. EASST review, 14(1), 14-19.

Ezeuduji, I. O. (2015). Strategic event-based rural tourism development for sub-Saharan Africa. Current Issues in Tourism, 18(3), 212-228.

Falak, S., Chiun, L. M., \& Wee, A. Y. (2014). A repositioning strategy for rural tourism in Malaysiacommunity's perspective. Procedia-Social and Behavioral Sciences, 144, 412-415. 
Farmaki, A. (2015). Regional network governance and sustainable tourism. Tourism Geographies, 17(3), 385407.

Lane, B. (2009). Rural tourism: An overview. In M. Robinson \& T. Jamal (eds.), The SAGE Handbook of Tourism Studies (pp. 354-370). Thousand Oaks, CA: Sage Publications.

Mason, P. (2015). Tourism impacts, planning and management. Arbingdon, UK: Routledge.

Montgomery, A. W., Dacin, P. A., \& Dacin, M. T. (2012). Collective social entrepreneurship: Collaboratively shaping social good. Journal of Business Ethics, 111(3), 375-388.

Mostafavi Shirazi, F., \& Mat Som, A. (2013). Relationship marketing and destination loyalty: Evidence from Penang, Malaysia. International Journal of Management and Marketing Research, 6(1), 95-106.

Mowforth, M., \& Munt, I. (2008). Tourism and sustainability: Development, globalisation and new tourism in the third world. Abingdon, UK: Routledge.

Nunkoo, R., Smith, S. L., \& Ramkissoon, H. (2013). Residents' attitudes to tourism: A longitudinal study of 140 articles from 1984 to 2010. Journal of Sustainable Tourism, 21(1), 5-25.

Pan, Z., Xu, W., Huang, Z., \& Wang, G. (2018). The effects of labour migration on rural household production in inland China: Do landform conditions matter? Population, Space and Place, 24(2), e2086. https://doi.org/10.1002/psp.2086

Peeters, P., \& Dubois, G. (2010). Tourism travel under climate change mitigation constraints. Journal of Transport Geography, 18(3), 447-457.

Reynaldi, B. (2018). An Analysis of Sustainable Tourism Development Collaboration: Case: Tourist Puppets Village of Kepuhsari, Wonogiri District. Paper presented at the International Conference of Communication Science Research (ICCSR 2018), July 24-25, Surabaya, Indonesia.

Sheresheva, M., \& Kopiski, J. (2016). The main trends, challenges and success factors in the Russian hospitality and tourism market. Worldwide Hospitality and Tourism
Themes, 8(3), 260-272.

Shie, E., \& Alipor Eshliki, S. (2010). Analysis of Quality Giving Factors of Coastal Tourism According To Stable Tourism's Parameters, Ramsar coast case study. Retrieved November 20, 2019, from http://touristy.blogfa.com/.

Strzelecka, M., Boley, B. B., \& Strzelecka, C. (2017). Empowerment and resident support for tourism in rural Central and Eastern Europe (CEE): The case of Pomerania, Poland. Journal of Sustainable Tourism, 25(4), 554-572.

Tolkach, D., \& King, B. (2015). Strengthening communitybased tourism in a new resource-based island nation: Why and how? Tourism Management, 48, 386-398.

Travelport. (2017). The Global Digital Traveler Research. Langley, Canada: Travelport.

Turner, R., \& Freiermuth, E. (2016). Travel \& Tourism Economic Impact 2016. London, UK: World Travel \& Tourism Council.

UNWTO/WTCF. (2018). City Tourism Performance Research. The World Tourism Organization (UNWTO). Retrieved November 20, 2019, from https:/www.eunwto.org/doi/book/10.18111/9789284419616

Viale, R., \& Ghiglione, B. (1998). The Triple Helix model: a Tool for the study of European regional socio economic systems. The IPTS Report, 29, 1-8.

Xiang, Z., Wang, D., O’Leary, J. T., \& Fesenmaier, D. R. (2015). Adapting to the internet: trends in travelers' use of the web for trip planning. Journal of Travel Research, 54(4), 511-527.

Yang, Y., Liu, X., Jing, F., \& Li, J. (2014). How does perceived value affect travelers' satisfaction and loyalty? Social Behavior and Personality: An International Journal, 42(10), 1733-1744.

Yu, C.-P., Chancellor, H. C., \& Cole, S. T. (2011). Measuring residents' attitudes toward sustainable tourism: A reexamination of the sustainable tourism attitude scale. Journal of Travel Research, 50(1), 57-63.

Zolfaghari, H. (2010). Tourism Climatology. Tehran, Iran: Agah Publication. 